\title{
The Fourteenath Amendment and the Poverty of African American ${ }^{1}$
}

\author{
Ravi Batra \\ Southern Methodist University
}

Following the Civil War Congress passed the 14th amendment to the constitution. It granted citizenship to African Americans and forbade any state government from taking away life, liberty or property of any person without due process of law. However, the amendment benefited the corporations with little help to black Americans. Each time a state decided to curb the monopoly power of a business, the courts would step in and proclaim that the state flouted the due process clause. This collusion between the government and corporations has contributed to high rates of poverty in America, especially among African American communities.

\section{INTRODUCTION}

The Civil War ended in 1865 and slavery was abolished. A sad chapter in American history was over, but another began soon thereafter. In order to improve the lot of former slaves, Congress passed the first civil rights act in 1866 and amended the constitution in 1868 with the $14^{\text {th }}$ amendment, which granted African Americans citizenship and gave people of "every race and color" equal rights. The amendment also introduced a due process clause, which barred state governments from depriving "any person of life, liberty and property without due process of law." (Hunt and Sherman,1972, p. 92)

However, for several decades, the amendment did little to protect the civil rights of the new American citizens, who were forced to live in misery and poverty - hardly better than slavery. Instead the law became an instrument for rich corporations for self-enrichment. Most federal courts ruled that corporations were persons and therefore entitled to protection under the due process clause. Each time a state government passed legislation to curb the antimonopoly and discriminatory practices of a corporation, federal courts would step in and proclaim the state regulations unconstitutional for flouting the due process clause of the amendment. State governments thus became helpless before the might of giant enterprises.

Unencumbered by any state intervention and with federal courts supporting them, corporations throve in America as never before. The economy grew at an unprecedented rate, while small businesses were gobbled up one by one by a few giants. Almost every major industry became a duopoly that earned huge profits from their practices, while working hours were long and real wages puny. African Americans faced extra hardship from these practices. They faced all sorts of discrimination, social as well as economic. Their unemployment was high and wages were well below those of the white people.

Congress passed the Sherman Anti-trust law in 1889 to outlaw the monopolizing activities of giant enterprises, but as with the $14^{\text {th }}$ amendment, this law was also abused by corporations with the help of their old friends - the federal courts. For the next few decades, the Sherman Act was used by courts to 
curb the activities of labor unions, while few businesses were barred from acquiring other profitable firms.

When firms have little competition, labor productivity rises but real wages lag behind. As a result, the wage-productivity gap grows over time, and creates poverty and unemployment in society. This is because productivity is the main source of the supply of goods and services, whereas the real wage is the main source of consumer demand. With the wage gap rising, supply rises faster than demand and results in overproduction, which in turn causes layoffs and a fall in the real wage.

The only way to cure unemployment and raise the real wage without recourse to Keynesian expansionary policies is to either break up the uncompetitive firms into smaller competing units or strengthen the labor unions to have a say in the setting of their wages. But Keynesian policies create consumer as well as federal debt and we can see that in the global economy today. Almost every nation has colossal debt by its government, and consumers are also heavily in debt, both of which generate stagnation.

\section{THE 1950s AND THE 1960s}

There are two decades in the long American chronicle that illustrate the power of a falling wage gap in reducing poverty for everyone in society. They are the 1950s and the 1960s. During the 1950s, the labor unions were just as strong as the giant enterprises, and the real wage actually grew faster than productivity. Big business faced big labor unions, so that there was some form of bilateral monopoly. The effect of this event is examined in Figure 1. The wage gap may be measured by

$\mathrm{WG}=$ productivity/real wage

If WG rises productivity rises faster than the real wage, and when WG falls the real wage grows faster than productivity. There are very few decades when the real wage outpaces productivity, and the most that we can expect is that the wage gap is low and stable. But whenever it falls, the effects on poverty and median income are phenomenal.

FIGURE 1

THE WAGE-GAP AND POVERTY - 1950S

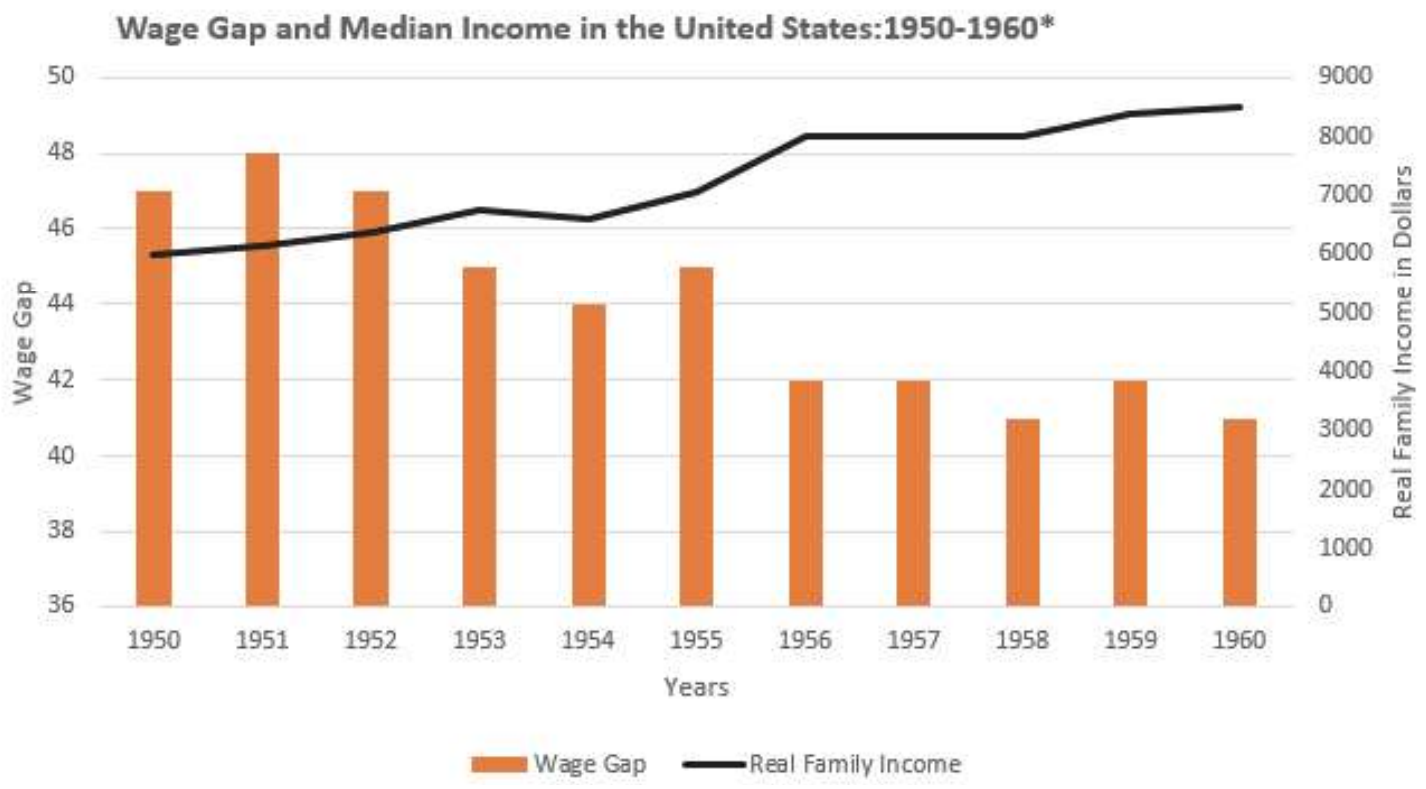

Source: Ravi Batra, End Unemployment Now: How to Eliminate Joblessness, Debt and Poverty Despite Congress, Palgrave - Macmillan, 2015. 
FIGURE 2

WAGE-GAP AND THE RATE OF PROFIT

Wage Gap and the rate of Profit in the United States (in \%):1950-

1960

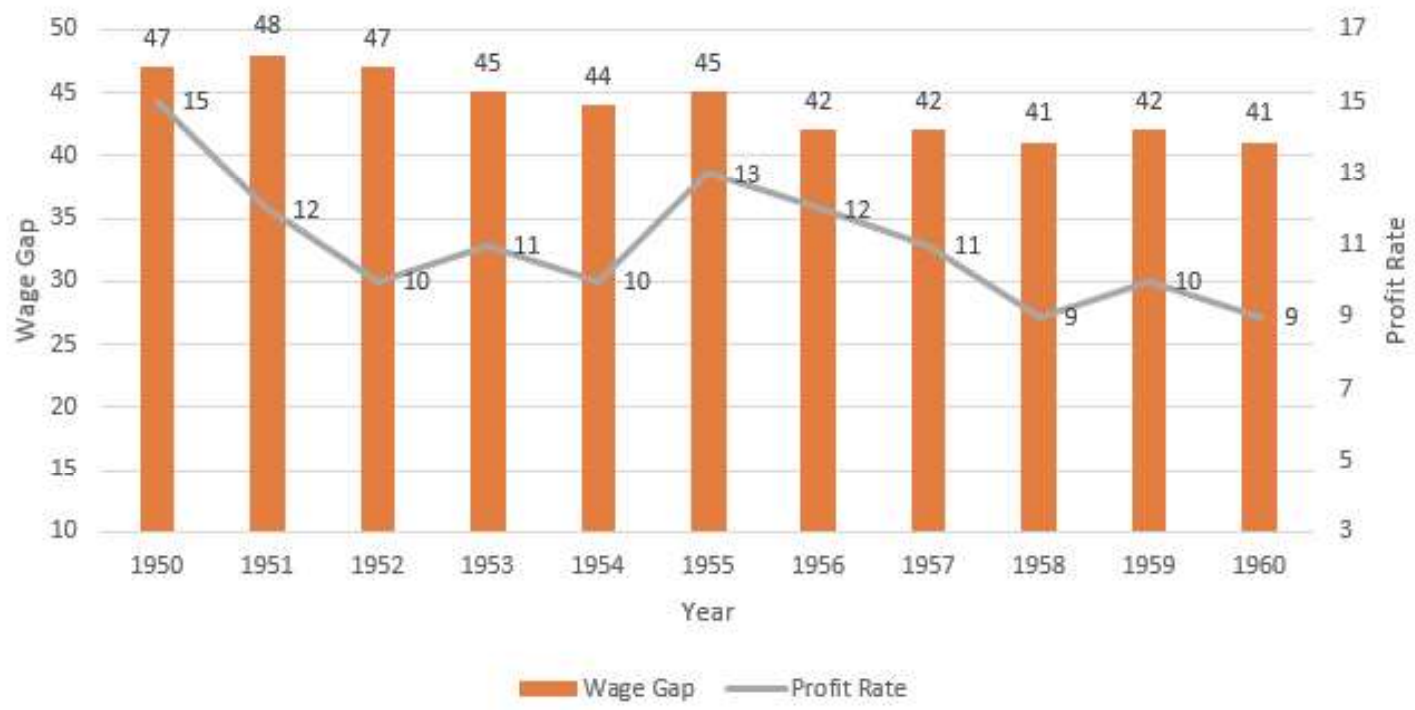

Source: Ravi Batra, End Unemployment Now, Palgrave - Macmillan, 2015.

FIGURE 3

WAGE GAP AND POVERTY: THE 1950S

Wage Gap and Poverty Level

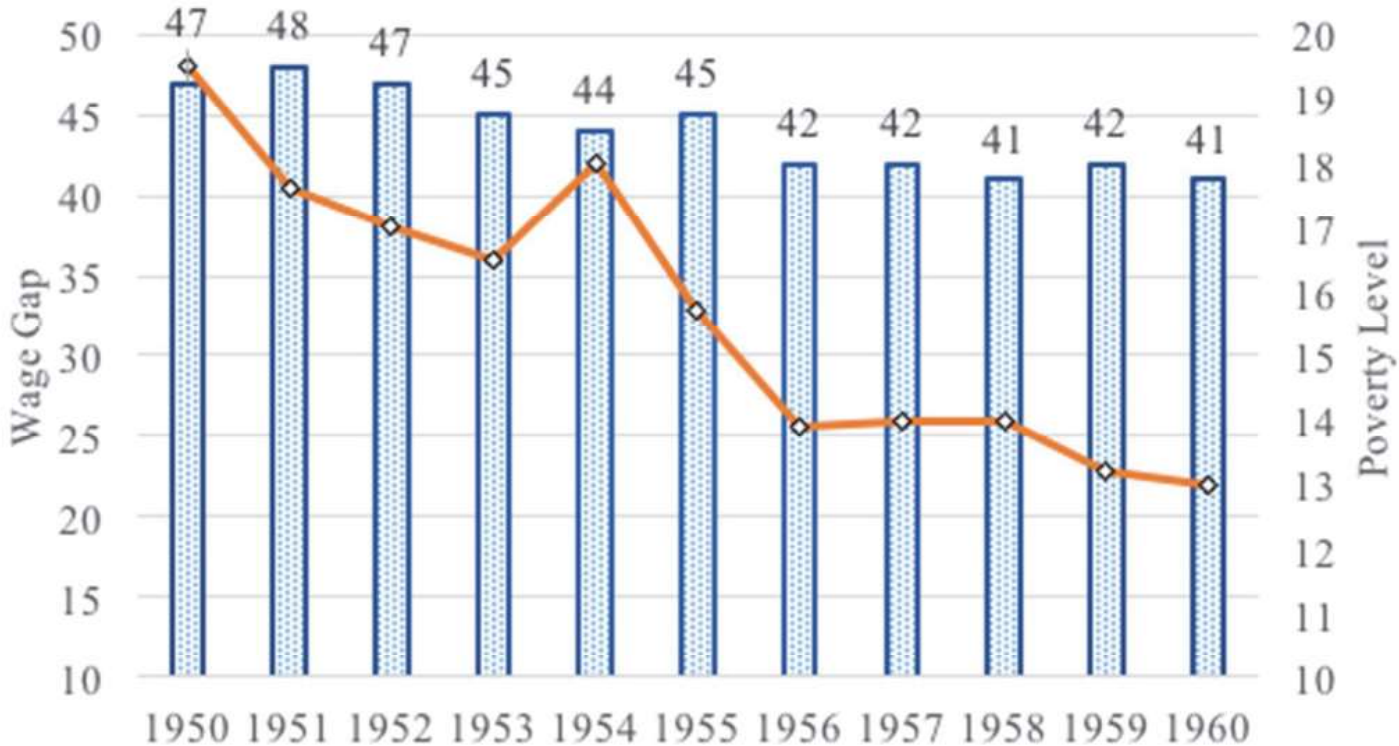

Wage Gap $\leadsto$ Poverty Level

Source: Ravi Batra: End Unemployment Now, Palgrave-Macmillan, 2015. 
Even during the recession years of 1951- 1952 and then 1959 - 1960, the median income kept growing, and as result poverty fell among all sections of society including African Americans. This much is clear from an observation of Figures 1 and 2. However, the rate of profit gradually fell, but was large enough to maintain high level of employment in the economy.

The 1950s were thus unprecedented. Never in American history has the wage gap declined so sharply. For median income to keep rising even during recessions says something about the power of bilateral monopoly that existed between big business and big unions. Figure 3 captures the full connection between the falling wage gap and the falling rate of poverty.

During the 1960s the wage gap remained stable at the low level achieved in the 1950s, and both GDP and productivity grew faster than in the previous decade. But thanks to strong labor unions, the real wage kept pace with productivity growth, and the wage gap remained constant. Poverty also fell faster than ever before for all groups, including African-Americans (See the Economic Report of the President, 1975).

The 1970s were not so kind because of the sharp rise in the price of oil, but poverty rates did not rise. Things changed substantially in the 1980s with the rise of supply side economics that led to a rise in tax rates for the poor and the middle class but a fall in taxes for the rich. Social security tax, self-employment tax, the gasoline tax, etc. went up, while the income tax rates declined sharply. Labor unions also became weak for a variety of reasons such as free trade and outsourcing.

The wage gap began to rise, and whatever GDP growth occurred required debt creation through Keynesian monetary and fiscal policies.

\section{FIGURE 4}

WAGE GAP AND THE POVERTY OF AFRICAN - AMERICANS: 2000 - 2016

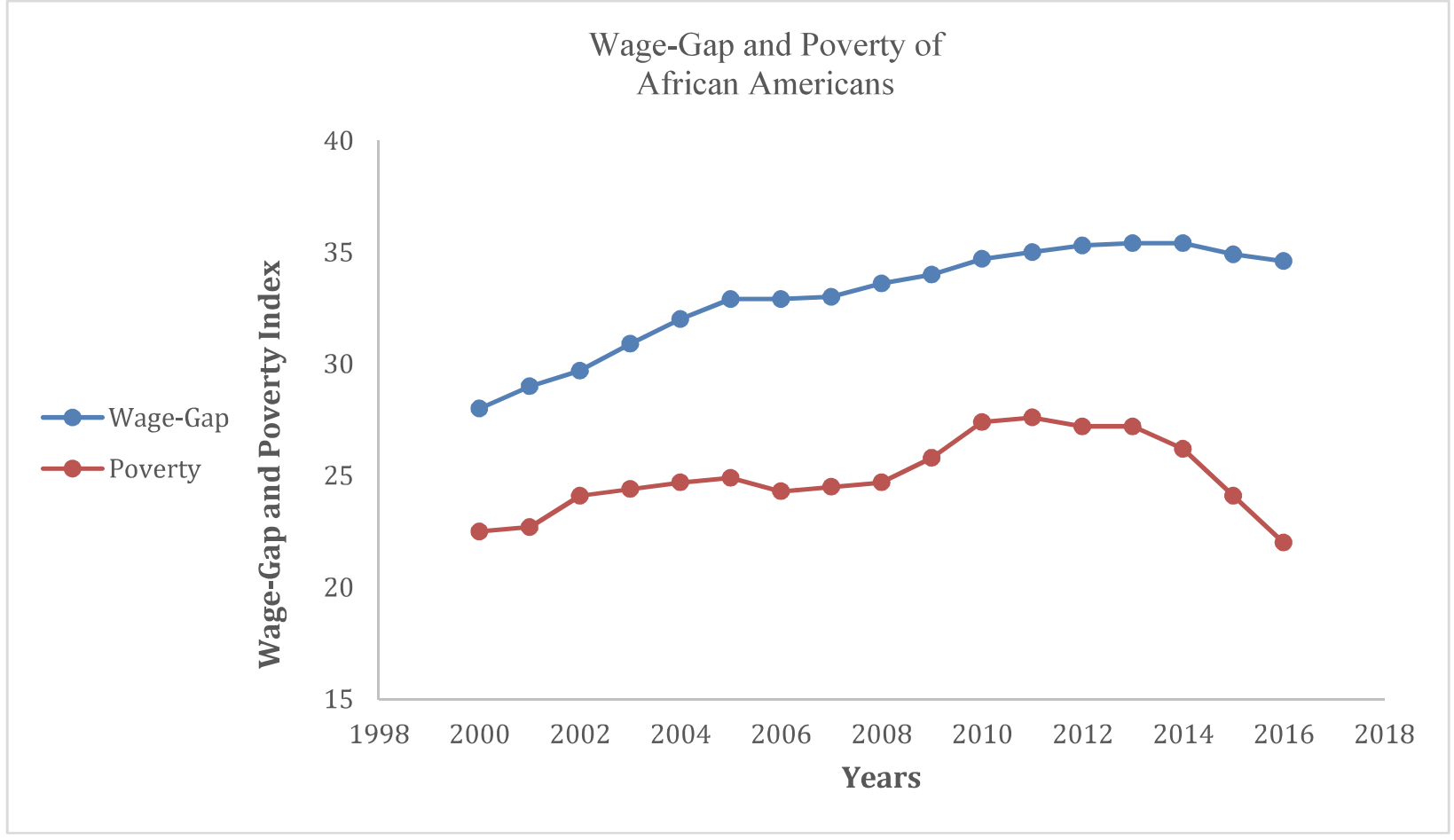

Source: Economic Report of the President, 2018 and 2009 


\section{THE GREAT RECESSION}

Let us now examine the data in the new millennium. The connection bwtween the rising wage gap and rising poverty of African - Americans becomes crystal clear. Figure 4 examines this from 2000 to 2016. The upper line describes the wage gap and the lower line the rate of poverty.

The two lines move well together. From 2000 to 2005, there was a sharp rise in the wage gap, and then the rate of poverty jumped from 22.5 percent to 24.9 percent. The wage gap stabilized somewhat and the poverty rate fell for 2006 . Then came the Great Recession of 2007 that simply decimated the poor and the middle class. Note that in the 1950s, the recessions did not cause a rise in poverty. Except for one year, 1953 - 1954, poverty fell throughout the 1950s. But the recession of 2007 was something else. Poverty rates sky-rocketed, and reached a high of 27.6 percent in 2011. According to the Census Bureau, poverty rates were the highest that year in the last 50 years.

The wage gap stabilized in 2012 and then fell somewhat. Poverty levels also then began to decline. The overall rate of poverty was about 12 percent among families in 2016, but for African - Americans, it was almost double that level at 22 percent.

\section{CONCLUSION}

The $14^{\text {th }}$ amendment to the constitution was meant to grant citizenship and equal economic rights. But the amendment ended up in creating duopolies and oligopolies. As a result, the constitutional change did not help the masses, and African Americans remained poor for a very long time. Rates of poverty fell steadily from 1950 to 1970 because of strong labor unions and then remained stable for another decade. They began to rise with the onset of the new economic creed called supply side theory, which was purely trickle down economics. Then came the Great Recession of 2007, which simply devastated the poor and the middle class. African Americans suffered badly during the recession. Wages and productivity have to grow proportionately for the economy to function well without the help of debt creation policies, which are popularly and euphemistically known as Keynesian policies, which only postpone problems. What we need is either high competition among firms or bilateral monopoly between giant firms and strong labor unions. Such indeed is the dictum of history.

\section{ENDNOTES}

1. This paper was presented at the American Social Sciennce Association meeting in Philadelphia on Janaury 7 , 2018.

\section{REFERENCES}

Batra, Ravi. (2015). End Unemployment Now: How to Eliminate Joblessness, Debt and Poverty Despite Congress, New York: Palgrave - Macmillan.

(1975) Counsel of Economic Advisers, Economic Report of the President

(2009) Counsel of Economic Advisers, Economic Report of the President

(2018) Counsel of Economic Advisers, Economic Report of the President

Sherman, E. K. and Hunt, H. J. (1972). Economics: An Introduction to Traditional and Radical Views, New York: Harper and Row. 